\title{
HUKUM ARISAN DAN KREDIT BANK UNTUK BERHAJI
}

\author{
Muh. Ahmad Rahmatullah, S.HI., M. H. \\ Institut Agama Islam Negeri (IAIN) Datokarama Palu \\ Muhammadahmad306668@gmail.com
}

\section{Abstrak}

Dewasa ini, antusias masyarakat Indonesia untuk berangkat haji ke tanah suci Makah semakin berkembang. Mulai kalangan pejabat, Pegawai Negeri Sipil (PNS) atau sekarang yang di ubah namanya menjadi Aparatur Sipil Negara (ASN) sampai pada masyarakat awam semua berlombalomba nebdaftarkan diri untuk berhaji. Maka tidak heran, antrian untuk berhaji saat ini disebagian daerah harus mengunggu 20 bahkan sampai 30 tahun. Namun ada hal menarik, karena saking tingginya antusias untuk berangkat haji, sebagian masyarakat Indonesia mengikuti sebuah program yang disebut arisan haji dan sebagian lain menggunakan fasilitas yang ditawarkan oleh beberapa bank untuk melakukan kredit haji. Oleh karena hal ini adalah sesuatu yang baru, maka ditemukan beberapa perbedaan pendapat ulama dalam menyikapinya, sebagian menghukuminya dengan haram dan sebagian lain memakruhkannya bahkan ada yang menghukuminya dengan mubah atau boleh-boleh saja.

Keyword: Arisan, Kredit Bank, Haji. 


\section{A. Latar belakang}

Di dalam kehidupan manusia tidak terlepas dari berbagai kebutuhan baik kebutuhan primer, sekunder maupun tertier. Untuk mencukupi kebutuhan hidup tersebut manusia tidak bisa melakukannya dengan sendiri tetapi membutuhkan orang lain. Hal ini sudah menjadi kodrat manusia yang diciptakan Allah Swt. untuk saling membutuhkan satu dengan yang lainnya. Supaya mereka saling tolong menolong, tukar menukar kebutuhan dalam segala urusan kepentingan hidup, baik dengan jalan jual beli, sewa-menyewa, hutang piutang, bercocok tanam atau dengan lainnya. Dengan melihat bagitu kompaknya hubungan dalam masyarakat, maka mereka dituntut untuk saling membantu sesama manusia dalam hal kebaikan salah satu contoh mereka saling membatu dalam hal pelaksaan ibadah haji.

Pada umumnya menunaikan ibadah haji memerlukan biaya yang tidak sedikit, dan merupakan ibadah termahal dari sisi material, khususnya bagi umat Islam yang tinggal di luar Jazirah Arab, sebagaimana halnya Indonesia, setiap muslim yang ingin menunaikan ibadah haji memerlukan biaya lebih dari tiga puluh juta rupiah. Besarnya biaya haji yang harus dikeluarkan membuat masyarakat menengah ke bawah kesulitan untuk melaksanakan rukun Islam yang kelima ini.

Ditengah masalah kemampuan materi yang menjadi tolak ukur kemampuan seseorang untuk berangkat haji, muncul suatu kebiasaan baru dalam masyarakat demi mencapai tujuan berhaji, misalnya menjual harta benda, membuka tabungan haji dan mengikuti arisan haji. Suatu kebiasan tersebut, arisan haji merupakan yang paling populer saat ini, hal ini disebabkan karena arisan merupakan hal yang sudah sangat mengakar dan sudah tumbuh sebagai bagian dari budaya masyarakat Indonesia. bahkan di beberapa kota besar di Indonesia, arisan telah menjadi gaya hidup bagi sekelompok 
orang-orang tertentu dan menjadi sebuah kebutuhan untuk memperoleh sesuatu yang diinginkan. Dengan maksud meringankan dan menolong orang-orang Islam yang tidak mempunyai bekal cukup untuk menunaikan ibadah haji.

Munculnya gagasan atau ide arisan haji sebagai solusi yang di gunakan untuk naik haji adalah mahalnya $\mathrm{ONH}$ (Ongkos Naik Haji) dan BPIH (Biaya Perjalanan Ibadah haji) di Indonesia dan kurang adanya motivasi atau semangat untuk menabung yang menjadikan arisan menjadi solusi bangi masyarakat menengah ke bawah untuk melaksanakan haji dengan sistem seperti arisan pada umumnya, dengan menyetorkan sejumlah uang yang telah ditentukan. Dalam waktu yang telah ditentukan pula, serta melakukan pengundian nama-nama yang akan diberangkatkan ibadah haji,

Di satu sisi, yang tidak kalah menariknya dengan sistem arisan di atas yaitu mengenai kredi bank itu sendiri masyarakat memandang adanya pembiayaan dana talangan haji sebagai alternatif yang cukup menarik untuk mengatasi masalah sulitnya berhaji, baik karena faktor pendanaan yang belum mencukupi maupun karena terbatasnya quota haji yang tersedia untuk calon jamaah haji di Indonesia. Namun di sisi lain, diduga ada unsur riba dalam praktek dana talangan haji. Hal ini karena praktek dana talangan haji mengharuskan calon jamaah haji membayar sejumlah uang lebih daripada yang dipinjamnya. ${ }^{1}$

Dikarenakan belum adanya kejelasan mengenai hukum arisan dan kredit bank untuk tujuan haji, maka penulis mencoba membahas lebih jauh mengenai hukum Arisan dan kredit bank untuk tujuan ibadah haji. Berdasarkan penjelasan tersebut di atas, maka penuelis dapat mengambil beberapa rumusan masalah sebagai berikut:

${ }^{1}$ Masyfuk Zuhdi, Masail Fiqhiyah: Kapita Selekta Hukum Islam,(Jakarta: CV Haji Masagung, 1991), h. 280.

Sangaji Jurnal Pemikiran Syariah dan Hukum 
1. Bagaimana Pengertian Mampu (Istitha'ah) yang Menjadi Syarat Wajib Haji?

2. Bagaiamana Hukum Arisan Untuk Tujuan Haji?

3. Bagaimana Hukum Kredit Bank Untuk Tujuan Haji?

\section{B. Mampu (Istitha'ah) yang Menjadi Syarat Wajib Haji}

Istitha'ah dalam pengertian kebahasaan berasal dari akar kata tha'a, yaitu tau'an, berarti taat patuh dan tunduk. Istitha'ah berarti keadaan seseorang untuk melakukan sesuatu yang diperintahkan syara' sesuai dengan kondisinya. Kata Istitha'ah artinya mampu, yaitu mampu melaksanakan ibadah haji ditinjau dari segi jasmani yaitu, sehat dan kuat, rohani yaitu, memahami manasik haji dan berakal sehat, ekonomi yaitu, mampu membayar penyelenggaraan ibadah haji dan memiliki biaya hidup bagi keluarga yang ditinggalkan. keamanan yaitu Aman dalam perjalanan dan aman bagi keluarga yang ditinggalkan².

Mengenai dalil istitha'ah yang menjadi dasar hukum kewajiban ibadah haji adalah QS. Ali- Imran ayat 97:

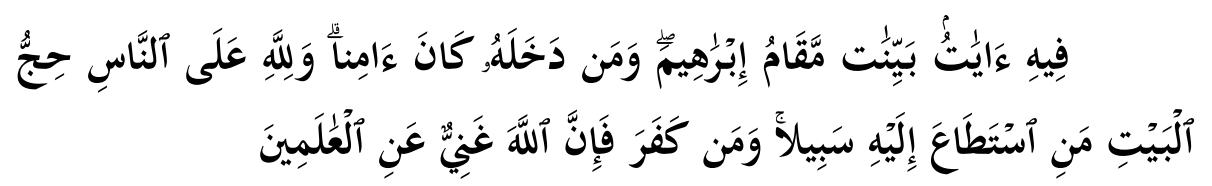

Terjemahnya:

"Dan (diantara) kewajiban manusia terhadap Allah adalah melaksanakan ibadah haji ke Baitullah, yaitu bagi orang-orang yang mampu mengadakan perjalanan kesana." ${ }^{3}$

Pengertian "mampu" Rasulullah Saw. menjelaskan bahwa adanya bekal dan kendaraan. Sedang mampu (istitha'ah) ada perbedaan penafsiran di kalangan Ulama. Menurut Rasyid

2 Departemen Agama RI, Bimbingan Manasik Haji, (Jakarta: 2003), h, 29

3 Departemen Agama RI, Al-Qur'an dan terjemahnya, (Jakarta: Mekar Surabaya, 2004), h. 78 
dan Muhammad Abduh, bahwa istitha'ah itu mampu untuk sampai ke Baitullah dan kemampuan itu berbeda-beda bagi tiap orang, tergantung kepada jauh atau dekatnya dari Baitullah dan kondisinya masing-masing. Tetapi kebanyakan Ulama menafsirkan istitha'ah dengan mempunyai bekal haji dan biaya transportasi pulang pergi di samping nafkah untuk keperluan keluarga yang ditinggalkan. ${ }^{4}$

Menurut para ulama, ada tiga kemampuan yang harus dipenuhi dalam rangka yang meliputi ibadah haji, yaitu: kemampuan kesehatan (badan), kemampuan material/finansial (keuangan), kemampuan keamanan (keselamatan) ${ }^{5}$

Adapun Perbedaan pendapat para ulama fiqh dalam memahami makna istitha'ah akan dijelaskan sebagai berikut:

1. Menurut Mazhab Hanafi ${ }^{6}$

Kesanggupan meliputi tiga (3) hal yaitu: fisik, finansial, maupun keamanan. Kesanggupan fisik artinya kesehatan badan. Adapun menurut golongan Hanafiyah, yang termasuk orang yang sakit, jika dia mampu untuk membayar ongkos kepada orang yang akan menggantikan hajinya, maka ia wajib haji, sebab ia terhitung orang kuasa dengan jalan mengongkosi orang. Kesanggupan finansial adalah memiliki bekal dan kendaraan. Yakni, mampu menanggung biaya pulang pergi serta punya kendaraan, yang merupakan kelebihan dari biaya tempat tinggal, serta keperluan lain. Harus lebih dari nafkah keluarga yang dinafkahinya sampai waktu kepulangannya. Adapun keamanan terkhusus bagi wanita sebaiknya menurut pendapat Abu Hanifah wanita harus diiringi oleh

${ }^{4}$ Masyfuk Zuhdi, Masail Fiqhiyah: Kapita Selekta Hukum Islam, , h. 283.

${ }^{5}$ Ahmad Thib Raya dan Siti Mushdah Mulia, Menyelami Seluk- Beluk Ibadah dalam Islam, (Jakarta: Prenada Media, 2003). h. 237

6 Wahbah Al-Zuhaily, Al-Figh al-Islamy waadillatuh, Juz III, (Suriah: Dar' al-Fikr, t.t.), h, 414.

Sangaji Jurnal Pemikiran Syariah dan Hukum 
mahramnya yang balig dan berakal atau remaja yang terpercaya, punya hubungan darah atau perkawinan.

\section{Mazhab Maliki ${ }^{7}$}

Kemampuan adalah bisa tiba di Mekah menurut kebiasaan, dengan berjalan kaki atau berkendaraan. Artinya, kesanggupan berangkat saja, adapun kesanggupan untuk pulang itu tidak termasuk hitungan. Kesanggupan itu meliputi tiga hal: Pertama, kekuatan badan. Artinya, dapat tiba di Mekah menurut kebiasaan, dengan berjalan ataupun dengan berkendaraan. Kedua, adanya bekal yang cukup sesuai dengan kondisi orang dan sesuai pula dengan kebiasaan mereka, Madzhab Maliki tidak mensyaratkan adanya bekal dan kendaraan, jalan kaki bisa menggantikan kendaraan, bagi orang yang mampu, dan keterampilan kerja yang mendatangkan pemasukan yang cukup bisa membuat seseorang tidak perlu membawa bekal atau uang dan bisa dikatakan cukup sebagai ganti bekal. Ketiga, tersedianya jalan, yaitu jalan yang dilalui (darat atau laut) dan biasanya jalan ini aman. Dan jika biasanya tidak aman maka itu tidak wajib haji.

\section{Mazhab Syafi'i ${ }^{8}$}

Memaknai istitha'ah dengan tiga hal yakni kemampuan fisik/badan, harta, dan kendaraan. Berhubungan dengan harta adalah yang mencukupi seseorang untuk melakukan perjalanan dan setelah pulang berhaji. Begitu pula bagi keluarga yang ia tinggalkan.

\section{Mazhab Hanbali}

Kesanggupan atau kemampuan yang disyariatkan adalah kemampuan atas bekal dan kendaraan. Seseorang wajib memiliki bekal dan kendaraan yang baik untuk

7 Wahbah Al-Zuhaily, Al-Figh al-Islamy waadillatuh), h, 416.

${ }^{8}$ Wahbah Al-Zuhaily, Al-Figh al-Islamy waadillatuh), h, 417. 
beribadah haji. Begitu pula tentang bekal bagi keluarga yang ditinggalkan selama ibadah haji wajib dicukupi. Bagi setiap orang Islam yang sudah mampu, beribadah haji hukumnya wajib. Berhaji berarti berupaya menyempurnakan posisi kehambaan di hadapan Allah Swt. Maka siapapun yang ingin berhaji harus mempersiapkan dirinya untuk memenuhi kebutuhannya untuk berhaji, baik dari segi material mau pun spiritual.

\section{Hukum Arisan Untuk Tujuan Ibadah Haji}

Bagi setiap orang Islam yang sudah mampu, beribadah haji hukumnya wajib. Berhaji berarti berupaya menyempurnakan posisi kehambaan di hadapan Allah Swt. Maka siapapun yang ingin berhaji hendaklah ia mempersiapkan dirinya untuk memenuhi kebutuhannya untuk berhaji, baik dari segi material maupun spiritual. Ketika membicarakan haji sebagai salah satu rukun Islam yang kelima bagi orang yang sudah mampu melaksanakannya. Mampu atau istitha'ah merupakan salah satu syarat melaksanakan ibadah haji. Maka mampu inilah yang menjadi permasalahan yang masih diperdebatkan. Kemudian ketika biaya ibadah haji menjadi permasalahan bagi masyarakat ekonomi menengah, dikarenakan ONH (Ongkos Naik Haji) dari tahun ke tahun bertambah mahal, maka munculah suatu sistem, yakni haji dengan sistem arisan.

Pandangan hukum Islam terhadap arisan haji adalah sebagai muamalah yang diperbolehkan, meskipun ongkos naik hajinya berubah-ubah. sehingga setoran yang harus diberikan oleh peserta arisan juga harus berubah-ubah. Sebab arisan itu menggunakan qirad (hutang piutang), sehingga perbedaan jumlah setoran tidak mempengaruhi keabsahan aqad tersebut. ${ }^{9}$

9 Dasar pengambilan Kitab Qolyubi juz 2 h. 258, dan Kitab Nihayatul Muhtaj juz 3 h. 233.

Sangaji Jurnal Pemikiran Syariah dan Hukum 
Menurut pendapat Ali Mustofa Yakub dalam bukunya mengatakan bahwa arisan sebenarnya menurut agama diperbolehkan, dengan catatan tidakadanya pihak yang dirugikan dan tidak adanya sistem perjudian didalamnya. Kebolehan itu juga bisa menjadi haram, jika ada sesuatu yang menjadikan haram, yaitu hilangnya ketentuan-ketentuan diatas $^{10}$.

Adapun dasar hukum bagi yang membolehkan hukum arisan secara umum, termasuk muamalat yang belum pernah disinggung dalam Al Quran dan sunnah secara langsung, maka hukumnya dikembalikan kepada hukum asal muamalah, yaitu dibolehkan. Para ulama menyebutkan hal tersebut dengan mengemukakan kaedah fikih yang berbunyi :

\section{الأصل في العقود والمعاملات الحل و الجواز}

Artinya:

"Pada dasarnya hukum transaksi dan muamalah itu adalah halal dan boleh."

Ibnu Taimiyah menyatakan di dalam Majmu' al Fatwa: "Tidak boleh mengharamkan muamalah yang dibutuhkan manusia sekarang, kecuali kalau ada dalil dari al Quran dan sunnah tentang pengharamannya" Para ulama tersebut berdalil dengan al Quran dan sunnah sebagai berikut :

Firman Allah Swt. Dalam al Quran Surat Luqman ayat 20.

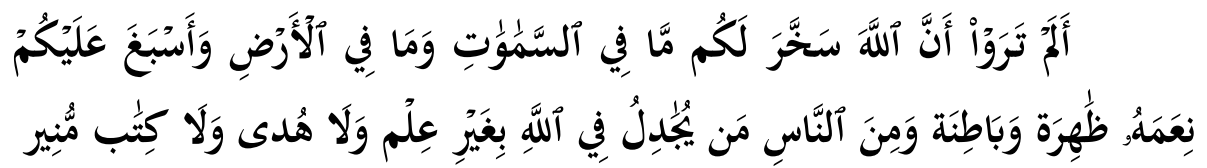

${ }_{10}$ Ali Mustofa Yakub, Fatwa-Fatwa Imam Besar Masjid Istiqlal, Cet 1,(Jakarta : PT Puataka Firdaus, 2007), h, 209 
Terjemahnya:

"Tidakkah kamu perhatikan Sesungguhnya Allah telah menundukkan untuk (kepentingan)mu dan apa yang di langit dan di bumi menyempurnakan untukmu nikmat-Nya lahir dan batin. dan di antara manusia ada yang membantah tentang (keesaan) Allah tanpa ilmu pengetahuan atau petunjuk dan tanpa kitab yang memberi penerangan." 11

Ayat di atas menunjukkan bahwa Allah Swt. memberikan semua yang ada di muka bumi ini untuk kepentingan manusia, para ulama menyebutnya dengan istilah (pemberian). Oleh karenanya, segala sesuatu yang berhubungan dengan muamalat pada asalnya hukumnya adalah mubah kecuali ada dalil yang menyebutkan tentang keharamannya. Kaitannya dengan" arisan" tidak kita dapatkan dalil baik dari al Quran maupun dari sunnah yang melarangnya, berarti hukumnya mubah atau boleh.

Firman Allah Swt. dalam al Quran surat al-Maidah ayat 2.

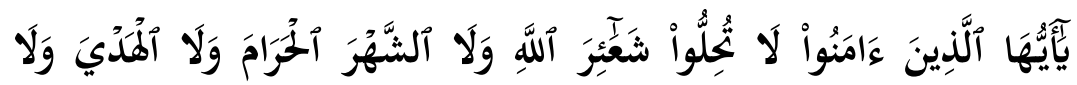

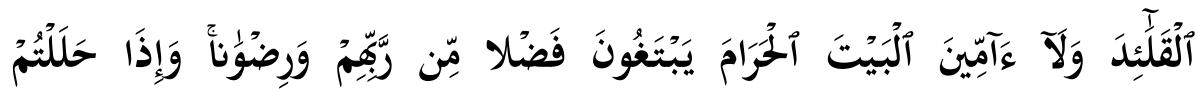

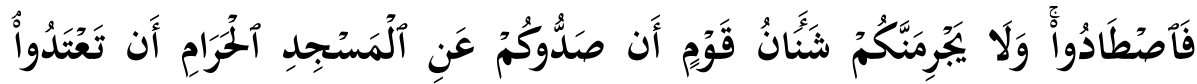

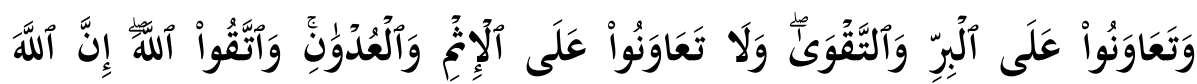

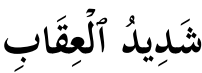

Terjemahnya:

"Hai orang-orang yang beriman, janganlah kamu melanggar syi'ar-syi'ar Allah', dan jangan melanggar kehormatan bulan-bulan

${ }^{11}$ Departemen Agama RI, Al-Qur'an dan terjemahnya, h. 584

12 Syi'ar Allah Ialah: segala amalan yang dilakukan dalam rangka ibadat haji dan tempat-tempat mengerjakannya.

Sangaji Jurnal Pemikiran Syariah dan Hukum 
haram $^{13}$, jangan (mengganggu) binatang-binatang had-ya ${ }^{14}$, dan binatang-binatang qalaa-id' dan jangan (pula) mengganggu orangorang yang mengunjungi Baitullah sedang mereka mencari kurnia dan keredhaan dari Tuhannya ${ }^{15}$ dan apabila kamu telah menyelesaikan ibadah haji, Maka bolehlah berburu. dan janganlah sekali-kali kebencian(mu) kepada sesuatu kaum karena mereka menghalanghalangi kamu dari Masji dilharam, mendorongmu berbuat aniaya (kepada mereka). dan tolong-menolonglah kamu dalam (mengerjakan) kebajikan dan takwa, dan jangan tolong-menolong dalam berbuat dosa dan pelanggaran. dan bertakwalah kamu kepada Allah, Sesungguhnya Allah Amat berat siksa-Nya."16

Ayat di atas memerintahkan untuk saling tolong menolong dalam kebaikan, sedang tujuan "arisan" itu sendiri adalah menolong orang-orang yang membutuhkan dengan cara mengumpul iuran secara rutin dan bergiliran untuk mendapatkannya, maka hal ini termasuk dalam katagori tolong menolong yang diperintahkan Allah Swt.

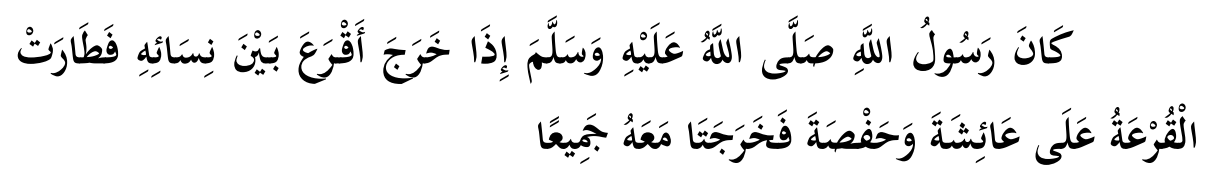

Artinya:

Rasulullah Saw. apabila pergi, beliau mengadakan undian diantara istri-istrinya, lalu jatulah undian itu pada

${ }^{13}$ Maksudnya antara lain Ialah: bulan Haram (bulan Zulkaidah, Zulhijjah, Muharram dan Rajab), tanah Haram (Mekah) dan Ihram. Maksudnya Ialah: dilarang melakukan peperangan di bulan-bulan itu.

14 Ialah: binatang (unta, lembu, kambing, biri-biri) yang dibawa ke ka'bah untuk mendekatkan diri kepada Allah, disembelih ditanah Haram dan dagingnya dihadiahkan kepada fakir miskin dalam rangka ibadat haji.

15 Dimaksud dengan karunia Ialah: Keuntungan yang diberikan Allah dalam perniagaan. Keredha'an dari Allah Ialah: pahala amalan haji.

${ }^{16}$ Departemen Agama RI, Al-Qur'an dan terjemahnya, h. 141 
Aisyah dan Hafsah, maka kamipun bersama beliau. (HR. Muslim).

Hadist di atas menunjukkan kebolehan untuk melakukan undian, tentunya yang tidak mengandung perjudian dan riba. Dalam arisan juga terdapat undian yang tidak mengandung perjudian dan riba, maka hukumnya boleh.

Pendapat para ulama tentang arisan, diantaranya adalah pendapat Syaikh Ibnu Utsaimin dan Syek Ibnu Jibrin serta mayoritas ulama-ulama senior Saudi Arabia. Syekh Ibnu Utsaimin berkata: "Arisan hukumnya adalah boleh, tidak terlarang. Barangsiapa mengira bahwa arisan termasuk kategori memberikan pinjaman dengan mengambil manfaat maka anggapan tersebut adalah keliru, sebab semua anggota arisan mendapatkan bagiannya sesuai dengan gilirannya masing-masing.

Adapun dari kalangan yang menolak Arisan sebagai tujuan ibadah haji para pakar hukum Islam (fuqaha') telah menerangkan di dalam kitab-kitab fikih, bahwa jika seseorang yang belum memiliki kemampuan (istitha'ah) untuk melaksanakan ibadah haji ditawari hadiah Biaya Perjalanan Ibadah Haji (BPIH) oleh yang lain, maka dia tidak wajib menerima hadiah tersebut.

Arisan Haji untuk membayar Biaya Perjalanan Ibadah Haji (BPIH) dengan tata cara sebagaimana disebutkan di atas atau yang serupa adalah dilarang oleh agama Islam, karena alasan-alasan sebagai berikut:

1. Arisan Haji dengan pola sebagaimana disebutkan di atas atau sesamanya adalah sama dan tidak berbeda dengan berhutang kepada orang lain. Sehingga memberatkan diri sendiri atau keluarga yang ditinggalkan jika ia wafat. Padahal Rasulullah Saw. telah melarang seseorang berhutang atau meminjam uang kepada orang lain untuk membayar Biaya Perjalanan Ibadah Haji (BPIH). 
Sebagaimana disebutkan dalam hadits yang diriwayatkan Imam Baihaqi: yang Artinya: "Sahabat Thariq berkata: Saya telah mendengar sahabat yang bernama Abdullah ibn Abi Aufa bertanya kepada Rasulullah Saw. tentang seseorang yang tidak sanggup naik haji apakah dia boleh meminjam uang untuk menunaikan ibadah haji? Nabi menjawab: Tidak boleh. (HR Baihaqi).

Menurut Kitab Al-Muhadzdzab bahwa seseorang yang berharta lalu kuasa berhaji maka ia harus berhaji. Tapi orang yang berharta tetapi mempunyai hutang yang harus segera di bayar maka baginya harus membayar hutangnya, dan tidak wajib berhaji. Berhaji seharusnya dan wajib dilaksanakan dengan perasaaan senang, dengan ketentuan mendahulukan membayar hutang daripada melaksanakan hajinya. ${ }^{17}$

2. Arisan Haji dengan pola sebagaimana disebutkan di atas atau yang serupa mengandung unsur gharar (kesamaran dan ketidak-jelasan) karena tidak ada jaminan bahwa orangorang yang telah memenangkan undian arisan haji mampu membayar lunas sisa arisan yang menjadi tanggungannya. Bagaimana jika orang-orang yang telah memenangkan undian arisan haji tertimpa musibah seperti meninggal dunia atau bangkrut sehingga tidak mampu membayar sisa arisan haji yang menjadi tanggungannya?. Apakah dapat dibebaskan sehingga mengakibatkan kerugian bagi anggota lain yang belum memperoleh kesempatan memenangkan undian. Atau dibebankan kepada keluarganya sehingga menimbulkan mudharat bagi anggota keluarga yang tidak tahu menahu soal arisan haji. Sehubungan dengan hal itu, Rasulullah Saw. bersabda yang artinya:

${ }^{17}$ Husein Bahreis, Himpunan Fatwa, (Surabaya: Al-Ikhlas, 1987), h. 255. 
Dari 'Amr bin Yahya al-Mazini dari ayahnya bahwa Rasulullah Saw. bersabda: "(Seseorang) tidak boleh melakukan tindakan yang merugikan diri sendiri atau merugikan orang lain".

3. Pada hakikatnya, seseorang yang telah berhasil memenangkan undian arisan haji sehingga berhak menunaikan ibadah haji dengan biaya yang diperoleh dari uang arisan adalah berhutang uang kepada para anggota arisan lainnya. Pinjaman tersebut harus di bayar lunas, meskipun secara berangsur-angsur sesuai dengan aturanaturan dalam arisan. Jika ia meninggal dunia atau jatuh bangkrut sebelum membayar lunas uang arisan, maka ia akan memikul beban hutang yang sangat berat. Karena hutang yang belum terbayar akan menjadi beban hingga di akhirat.

4. Seseorang yang akan menunaikan ibadah haji harus membayar Biaya Perjalanan Ibadah Haji (BPIH); mempunyai biaya hidup yang cukup selama berada di tanah suci; serta biaya keluarga yang ditinggalkan di tanah air dengan uang yang diperoleh secara halal, suci dan bersih dari segala sesuatu yang mengotorinya. Sebab jika uang tersebut diperoleh dari sumber yang tidak halal atau tidak suci dan tidak bersih, maka tidak akan diterima oleh Allah swt sehingga tidak akan meraih haji mabrur.

Dari uraian diatas, jelas bahwa kewajiban haji itu, hanya berlaku bagi orang yang sanggup membayar BPIH. Maka seorang muslim yang memaksakan dirinya untuk menunaikan ibadah haji, padahal ia tidak mampu, misalnya dengan cara mengikuti arisan haji dan ia mendapatkan uang arisan pada putaran-putaran awal, maka hukumnya minimal makruh bahkan bisa juga haram, karena ongkos hajinya itu berasal dari uang yang dipinjamkan oleh anggota arisan lainnya. Jadi ia 
berangkat haji dengan berhutang. Sementara ia sendiri belum terkena khitab wajib haji. ${ }^{18}$

\section{Hukum Kredit Bank Untuk Tujuan Ibadah Haji}

Kesulitan menunaikan ibadah haji pada umumnya dirasakan oleh sebagian masyarakat menengah ke bawah, akan tetapi seiring berjalannya waktu kaum muslimin yang belum memiliki kemampuan penuh untuk menunaikan ibadah haji bisa melaksanakan ibadah haji dengan dana talangan haji dari salah satu LKS (Lembaga Keuangan Syariah).

Dana talangan haji adalah sebuah produk lembaga keuangan syariah baik bank dan non-bank yang memberikan fasilitas pinjaman dana bagi nasabah yang hendak menunaikan ibadah haji, yang mana bertujuan untuk menutupi kekurangan dana guna memperoleh kursi haji saat pelunasan biaya perjalanan ibadah haji (BPIH).

Dana talangan ini di jamin dengan deposit yang dimiliki nasabah. Nasabah kemudian wajib mengembalikan sejumlah uang yang di pinjam dalam jangka waktu tertentu. Atas jasa peminjaman dana talangan ini, Bank Syariah memperoleh imbalan (fee/ujrah). Perlu diketahui dalam pengertian diatas fasilitas pinjaman dana disini dijelaskan bahwasanya kepergian jamaah haji, tidak dalam kondisi terhutang, karena sudah dilunasi sebelum berangkat haji, hanya saja untuk mendapatkan seat dari Kementerian Agama, bank syariah memberikan talangan untuk meringankan nasabah. Oleh karena itulah DSN MUI membolehkan dana tangan haji tersebut.

Dari sisi ruh pelaksanaan haji, tentu melaksanakan ibadah haji dengan dana talangan bertentangan dengan makna "Kemampuan" dan cenderung memaksakan di luar batas kemampuan serta anjuran untuk menghindari hutang. Adapun

${ }^{18}$ Husein Bahreis,, Himpunan Fatwa, h. 255 
dari sisi hukum boleh atau tidaknya, terdapat dua pandangan antara yang membolehkan dan yang mengharamkan

Dasar hukum produk dana talangan haji tidak dijelaskan secara eksplisit dalam Al Quran, sunnah, Ijma', dan Qiyas. Produk ini berkaitan dengan bidang muamalat yang berkembang sedemikian rupa dan belum dipraktikkan oleh nabi, sahabat, dan ulama-ulama terdahulu. Sehingga dasar hukumnya dapat kita dapatkan dari fatwa Dewan Syariah Nasional MUI Nomor 29/DSN-MUI/VI/2002.

Adapun fatwa tersebut memutuskan kebolehan produk ini berdasarkan dalil-dalil sebagai berikut, QS. Al Maidah ayat 1 .

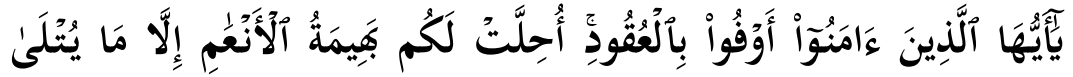

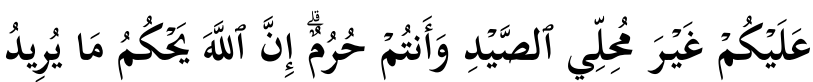

Terjemahnya:

"Hai orang-orang yang beriman, penuhilah aqad-aqad itu". Dihalalkan bagimu binatang ternak, kecuali yang akan dibacakan kepadamu. (yang demikian itu) dengan tidak menghalalkan berburu ketika kamu sedang mengerjakan haji. Sesungguhnya Allah menetapkan hukum-hukum menurut yang dikehendaki-Nya." 20

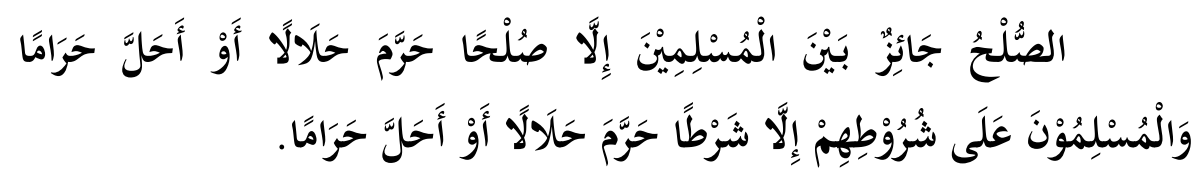

Artinya:

"Perjanjian boleh dilakukan di antara kaum muslimin kecuali perjanjian yang mengharamkan yang halal atau menghalalkan yang haram; dan kaum muslimin terikat dengan syarat-syarat mereka

${ }^{19}$ Aqad (perjanjian) mencakup: janji prasetia hamba kepada Allah dan Perjanjian yang dibuat oleh manusia dalam pergaulan sesamanya.

${ }^{20}$ Departemen Agama RI, Al-Qur'an dan Terjemahnya, h. 141

Sangaji Jurnal Pemikiran Syariah dan Hukum 
kecuali syarat yang mengharamkan yang halal atau menghalalkan yang haram." (HR Tirmizi dari 'Amr bin 'Auf al-Muzani)

Selanjutnya dijelaskan dalam kaidah fikih

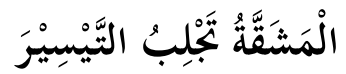

Artinya:

"Kesulitan dapat menarik kemudahan"

Fatwa Dewan Syari'ah Nasional Nomor: 29/DSNMUI/VI/2002 Tentang Pembiayaan Pengurusan Haji Lembaga Keuangan Syari'ah, memang memiliki dua jenis akad yakni alqardh dan al-ijarah, Pertama, akad al-qardh (pinjaman) dengan obyek uang, di sini nasabah hanya mengembalikan sejumlah yang dipinjam. Kedua, Ijarah berarti sewa, jasa atau imbalan, yaitu akad yang dilakukan atas dasar suatu manfaat dengan imbalan jasa. ${ }^{21}$

Akad ijarah al 'amal (sewa jasa), yaitu jasa pengurusan haji. Sebagaimana yang telah diketahui bahwa al-ijarah ada dua jenis: ijarah al-maal (sewa barang) dan ijarah al 'amal (sewa jasa). Bila pada jual beli obyek transaksinya adalah barang, maka para ijarah obyek transaksinya adalah barang atau jasa. ${ }^{22}$

Sementara yang dimaksud dalam Fatwa MUI di sini adalah ijarah al 'amal. Oleh sebab itulah dalil-dalil ijarah yang diketengahkan dalam Fatwa DSN itu adalah berkaitan langsung dengan ijarah al 'amal, bukan ijarah al maal. Ini juga ditegaskan dalam ketentuan umum, bahwa dalam pengurusan haji bagi nasabah, LKS dapat memperoleh imbalan jasa (ujrah) dengan menggunakan prinsip al-ijarah. Nama fatwanya saja adalah "pembiayaan pengurusan", dan bukan "pinjaman dana haji". Oleh sebab itu, ada penegasan ketentuan yang berbunyi:

${ }^{21}$ Habib Nazir dan Muh. Hasan, Ensiklopedi Ekonomi dan Perbankan S yari'ah, (Bandung: Kaki Langit, 2004), h. 246.

${ }^{22}$ Karim Adiwarman, Bank Islam: Analisis Fiqih dan Keuangan, (Jakarta: The International Institute of Islamic Thought, 2003), h. 105. 
Jasa pengurusan haji yang dilakukan LKS tidak boleh dipersyaratkan dengan pemberian talangan haji. Maka dari itu, antara akad ijarah al 'amal (sewa jasa pengurusan haji) dengan al-qardh (pinjaman/talangan) sebetulnya adalah terpisah.

Pada dasarnya berhaji dengan berhutang itu tidak diperbolehkan, hal ini berdasarkan hadits yang diriwayatkan oleh'Abdullah bin Abi 'Aufa, yang terjemahnya: "Saya tanyakan kepada Rasulullah Saw. Mengenai orang yang belum menunaikan haji, apakah ia boleh berutang buat berhaji? " Ujarnya: “Tidak!" (H.R. Baihaqi).

Larangan ini terjadi karena Islam tidak menghendaki orang berhaji dengan membawa beban hutang. Pada perkembangannya, belakangan ini di beberapa negara untuk dapat pergi haji orang harus menunggu bertahun-tahun, hal ini karena panjangnya daftar antri di samping adanya kuota dari otoritas Arab Saudi. Maka orang yang berhutang misalnya meminjam dari bank, dipastikan sudah lunas pinjamannya pada saat mendapat giliran pergi hajinya, sehingga dia bisa pergi tanpa meninggalkan beban hutang lagi. ${ }^{23}$

Namun Pendapat terkait dengan hukum kredit bank untuk tujuan ibadah haji dalam Syariat Islam sebagai berikut:

\section{Fatwa Majelis Ulama Indonesia}

Majelis Ulama Indonesia tak mempermasalahkan mekanisme penggunaan dana talangan dalam pelaksanaan haji. "Sudah ada fatwanya, mekanisme dana talangan dibolehkan secara syariah "mekanisme pinjaman ke bank untuk pelaksanaan haji dibolehkan, asalkan tidak ada imbalan atau komisi dalam talangannya. Komisi hanya boleh diterapkan perbankan dalam proses pengurusannya.

${ }^{23}$ Maadi ghufran. Fiqih muamalah kontekstual, (Jakarta: Raja Grapindo persada, 2002), h. 27

Sangaji Jurnal Pemikiran Syariah dan Hukum 


\section{Fatwa Ulama NU}

Fatwa yang sama juga telah ditetapkan para ulama NU dalam Muktamar ke-28 di Pondok Pesantren alMunawwir Krapyak, Yogyakarta pada 25-28 November 1989. Dalam fatwanya, ulama NU bersepakat bahwa: Mengambil kredit tabungan dengan jaminan dan angsuran dari gaji untuk membiayai ibadah haji adalah sah. "Hukum hajinya sah," demikian bunyi fatwa tersebut. Sebagai dasar hukumnya, para ulama NU mengambil dalil darialSyarqawi, Juz I, halaman 460: "Orang yang tidak mampu, maka ia tidak wajib haji, akan tetapi jika ia melaksanakannya, maka hajinya sah." Dalil lainnya yang digunakan sebagai dasar hukum adalah Nihayatul Muhtaj, Juz III, halaman 223: "Sah haji orang fakir dan semua yang tidak mampu selama ia termasuk orang merdeka dan mukallaf (Muslim, berakal dan balig), sebagaimana sah orang sakit yang memaksakan diri untuk melaksanakan shalat Jumat." 24

\section{Pendapat Syekh Muhammad bin Shalih}

Terkait menunaikan haji dengan uang pinjaman, Syekh Muhammad bin Shalih alUtsaimin, dalam Fatawa Nur 'alad Darb, jilid 1 hal 277, mengungkapkan: Haji dengan uang dari utangan tidak merusak sahnya ibadah haji. Apalagi bila di balik utang itu ada tujuan yang mulia, yaitu menemani orang tua, atau wanita yang tidak memiliki mahram. Seseorang, kata Syekh al-Utsaimin, tidak wajib menunaikan ibadah haji jika ia sedang menanggung utang, tapi tidak menggugurkan syarat sahnya. Sebagian ulama, berpandangan; jangan berutang untuk menunaikan ibadah haji, karena ibadah haji dalam kondisi seperti itu hukumnya tidak wajib. Dengan

24Teungku Muhammad Hasbi Ash-Shiddieqy, Pedoman Haji, (Semarang: Pustaka Rizki Putra, 1998), h.17-19 
kemurahan rahmat Allah Swt, seseorang hendaknya tidak memaksakan diri dengan berutang, yang ia sendiri tidak tahu kapan dapat melunasinya, bahkan barangkali ia mati dan belum sempat menunaikan utangnya. Lalu jika begitu ia menanggung beban hutang selama-lamanya. Syekh alUtsaimin membolehkan kredit di bank untuk bisa berangkat haji. $^{25}$

Adanya perbedan tentang boleh tidaknya kredit bank untuk tujuan haji karena kredit bank itu sendiri memberikan manfaat yang sangat besar begitupula sebaliknya. Tidak bisa dipungkiri bahwa sebuah produk tentu memiliki sisi positif dan negatif. Manfaat utama dari produk ini (Dana Talang Haji) adalah memberikan bantuan kepada masyarakat untuk melaksanakan salah rukun Islam yakni berhaji ke Baitullah.

Namun disisi lain terdapat banyak mudarat yang timbul dari praktek dana talangan haji ini, baik ditinjau dari aspek syariah yakni keabsahan akadnya yang sangat riskan menjatuhkan kepada riba tersembunyi, karena dalam akad ini terjadi penggabungan antara akad al-qardh dan al-ijarah dengan mensyaratkan adanya tambahan imbalan sebagai jasa, bahkan tambahan tersebut besarnya tergantung pada masa pinjaman. Dan terkesan ingin memaksakan diri dengan cara berhutang, padahal ia belum termasuk orang yang berkewajiban melaksanakan ibadah haji.

Jika dilihat dari aspek sosial, adanya dana talangan haji menyebabkan berbondong-bondongnya masyarakat untuk mendaftarkan diri guna mendapatkan seat haji dengan bantuan dari dana talangan haji meskipun sebenarnya mereka belum sanggup membayarnya. Hal ini menyebabkan membengkaknya peserta tunggu sehingga banyak orang yang sebenarnya sudah mampu namun "diserobot" antriannya oleh

25Teungku Muhammad Hasbi Ash-Shiddieqy, Pedoman Haji, h. 19

Sangaji Jurnal Pemikiran Syariah dan Hukum 
mereka yang memakai jasa talangan haji dan antriannya mundur bahkan sampai bertahun-tahun.

Dalam ushul fikih kita mengenal kaidah yang berbunyi;

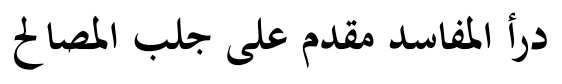

Artinya :

"Menolak kemudaratan lebih diutamakan dari pada mencari kemaslahatan."

\section{E. Kesimpulan}

1. Istita'ah (kemampuan) yang merupakan syarat wajib ibadah haji, baik secara finansial, fisik, maupun memenuhi keperluan dalam perjalanan. Mampu secara finansial adalah memiliki biaya ibadah haji dengan dirinya sendiri. Orang yang belum memiliki harta yang dimiliki dari dirinya sendiri belum di wajibkan untuk melaksanakan ibadah haji. Bahkan kalua ada orang yang memberinya uang agar berangkat haji, maka dia tidak wajib menerimanya. Karena itu bukan termasuk kemampuan dari dirinya sendiri. Jumhur ulama mazhab menetapkan bahwa istitha'ah atau mampu itu merupakan syarat kewajiban haji sesui dengan surat al Ilmran ayat 97 tersebut.

2. Arisan hukumnya adalah boleh, tidak terlarang. Barangsiapa mengira bahwa arisan termasuk kategori memberikan pinjaman dengan mengambil manfaat maka anggapan tersebut adalah keliru, sebab semua anggota arisan akan mendapatkan bagiannya sesuai dengan gilirannya masing-masing. Namun pendapat lain mengatakan bahwa seorang muslim yang memaksakan dirinya untuk menunaikan ibadah haji, padahal ia tidak mampu, misalnya dengan cara mengikuti arisan haji dan ia mendapatkan uang arisan pada putaran-putaran awal, maka hukumnya minimal makruh bahkan bisa juga haram, karena ongkos hajinya itu berasal dari uang ya ng 
dipinjamkan oleh anggota arisan lainnya. Jadi ia berangkat haji dengan berhutang. Sementara ia sendiri belum terkena khitab wajib haji.

3. Dasar hukum produk dana talangan haji tidak dijelaskan secara eksplisit dalam Al Quran, sunnah, Ijma', dan Qiyas. Produk ini berkaitan dengan bidang muamalat yang berkembang sedemikian rupa dan belum dipraktikkan oleh nabi, sahabat, dan ulama-ulama terdahulu. Sehingga dasar hukumnya dapat kita jumpai dari fatwa Dewan Syariah Nasional MUI Nomor 29/DSN-MUI/VI/2002. Jadi mekanisme pinjaman ke bank untuk pelaksanaan haji dibolehkan, asalkan tidak ada imbalan atau komisi dalam talangannya. Komisi hanya boleh diterapkan perbankan dalam proses pengurusannya.

Sangaji Jurnal Pemikiran Syariah dan Hukum 


\section{Daftar Pustaka}

Adiwarman, Karim. Bank Islam: Analisis Fiqih dan Keuangan, Jakarta:

The International Institute of Islamic Thought, 2003

Ash Shiddieqy, Teungku Muhammad Hasbi, Pedoman Haji, (Semarang: Pustaka Rizki Putra, 1998).

Ahmad Thib Raya dan Siti Mushdah Mulia, Menyelami SelukBeluk Ibadah dalam Islam, Jakarta: Prenada Media, 2003

Al-Zuhailiy, Wahbah, al-Figh al-Islami wa Adillatuhu. Juz III. Beirut Dar al-Fikr, t.t.

Bahries, Husein, Himpunan Fatwa, Surabaya: Al-Ikhlas, 1987

Departemen Agama RI, Bimbingan Manasik Haji, Jakarta: 2003

Departemen Agama RI, Al Quran dan terjemahnya, Jakarta: Mekar Surabaya, 2004

Mustofa Yakub, Ali, Fatwa-Fatwa Imam Besar Masjid Istiqlal, Cet 1, Jakarta : PT Puataka Firdaus, 2007

Ghufran, Maadi. Fiqih muamalah kontekstual, (Raja Grapindo persada : Jakarta, 2002).

Poerwadarminta, Kamus Bahasa Indonesia, Jakarta: Balai Pustaka, 1999

Zuhdi, Masyfuk, Masail Fighiyah: Kapita Selekta Hukum Islam, Jakarta: CV Haji Masagung, 1991 